ISSN 1997-0854 (Print), 2587-6341 (Online)

DOI: $10.33779 / 2587-6341.2021 .3 .123-136$

UDC 784.1

NATALYA V. KOSHKAREVA

State Musical Pedagogical Institute named after M. M. Ippolitov-Ivanov

Moscow, Russia

ORCID:0000-0003-3831-3419,nkoshkarevav@gmail.com

\title{
A Multimodal Analysis of Hommage à Marina Tsvetayeva by Sofia Gubaidulina
}

The article reveals the stylistic features of the contrapuntal technique Sofia Gubaidulina applied in her choral composition Hommage à Marina Tsvetaeva. This study analyzes Sofia Gubaidulina's contrapuntal technique of synthesizing the poetic and musical texts. It examines the genre archetypes of each movement of the suite, analyzes the types of contrapuntal approaches in terms of the parameters of tradition and innovation, and carries out a contextual analysis of the suite as an exemplary contemporary choral composition. The five movements of the composition are categorized into three genre archetypes (canon, motet, and psalmody), five types of contrapuntal techniques (canonical imitation, hoquet, antiphon, continuous imitation and responsory) and four types of 20th century compositional techniques (sonorism, pointillism, quotations and sonoric aleatory technique). Nine vocal techniques and five types of vocal sound are utilized in this composition. These vocal techniques and types of sounds are especially distinctive in the third, fourth, and fifth movements of the work. This is, in all likelihood, the first article to examine the technique of contrapuntal writing as a separate phenomenon in contemporary Russian music on the example of Sofia Gubaidulina's composition of Hommage à Marina Tsvetaeva, written in the genre of a cycle of pieces for a cappella chorus.

Keywords: Sofia Gubaidulina, Marina Tsvetaeva, contemporary polyphonic writing, choral polyphony, choral suite, canon, psalmody, motet.

For citation / Для иитирования: Natalya V. Koshkareva. A Multimodal Analysis of Hommage à Marina Tsvetayeva by Sofia Gubaidulina // Проблемы музыкальной науки / Music Scholarship. 2021. № 3. C. 123-136. DOI: 10.33779/2587-6341.2021.3.123-136.

(C) Natalya V. Koshkareva, 2021

(C) Publisher: Scholarly-Methodical Center "Innovation Art Studies," 2021

\section{Н. В. КОШКАРЕВА}

Государственный музыкально-педагогический институт имени М. М. Ипполитова-Иванова

2. Москва, Россия

ORCID: 0000-0003-3831-3419,nkoshkarevav@gmail.com

\section{Мультимодальный анализ «Посвящения Марине Цветаевой» Софии Губайдулиной}

В статье раскрываются стилистические особенности полифонического письма Софии Губайдулиной, использованного ею в хоровой композиции «Посвящение Марине Цветаевой». 
Показаны результаты анализа техники полифонического письма Софии Губайдулиной в синтезе поэтического и музыкального текста. Рассматриваются жанровые архетипы каждой части сюиты, анализируются типы полифонического подхода с точки зрения традиции и новаторства, проводится контекстуальный анализ сюиты как современной хоровой композиции. Пять частей композиции были разделены композитором на три жанровых архетипа (канон, мотет и псалмодия), пять полифонических техник (каноническая имитация, хокку, антифон, имитация непрерывности и отзывчивость) и четыре композиционных техники (сонорика, пуантилизм, аллюзия и сонорика-алеаторика). Автор использовал девять вокальных приёмов и пять звуков. Они ярко проявили себя в третьей, четвёртой и пятой частях сочинения. На примере произведения Софии Губайдулиной «Посвящение Марине Цветаевой», написанного в жанре сюиты для хора a cappella, статья впервые рассматривает полифоническое письмо как самостоятельное явление в современной русской музыке.

Ключевые слова: София Губайдулина, Марина Цветаева, современное полифоническое письмо, хоровая полифония, хоровая сюита, канон, псалмодия, мотет.

(C) Кошкарева Н. В., 2021

(C) Издатель: АНО ДПО НМЦ «Инновационное искусствознание», 2021

\section{Introduction}

The artistic legacy of Sofia Gubaidulina holds a specific place in the history of world musical culture of the 20th and early 21st centuries. Gubaidulina's music is widely known throughout the world. Sofia Gubaidulina incorporates contrapuntal writing which follows other composers, inheritors of the legacy of the Viennese Classicists, such as Dmitri Shostakovich, Alexander Scriabin, and Olivier Messiaen ${ }^{1}$ (Fanning and Assay 2019; Artamonova 2019 [4; 11], and etc.). Numerous musicologists have studied her choral styles (Kholopova 1973 [3], and etc.). Other music scholars have studied her rhythmic and numerical structures, the originality of her sonoristic pieces [1, p. 121] and her instrumental compositions (Moskvina 2015, and etc.). However, only a few scholarly works (e.g., Kholopova 1973) have explored the artistic heritage and spiritual nature of Sofia Gubaidulina's music.
This work carries out a semantic analysis of the spiritual nature of the poetical texts the composer has set to her music to fill this exsting gap. Awang (2016) ${ }^{2}$ stated that Peynircioglu's poetical texts play a significant role in evoking the listeners' emotions through the melody inherent in the songs. The poetical texts combined with melodies evoke the audience's senses and emotions by means of a semantic process, thereby enhancing their perception of their message. Therefore, the composer's focus is on innovative techniques which enhance choral counterpoint. Gubaidulina's musical compositions reveal three types of genre archetypes, which are canon, psalmody, and motet (Warwick 2011 [20]). These prototypes symbolize the eternity of spiritual entities and the infinity of historical and temporal categories. By bringing in innovative tone painting methods and referring to compositions written in different years, as well as the poetic cycles set to music by her, Gubaidulina managed to express her desperation and alienation sense 
of from the world (Dyganova 2017 [10]). This combination has made Gubaidulina's musical legacy distinctly different from that of other composers. Research has shown that composers find it more challenging to emphasize and demonstrate the poetry they set to music by making use of various contrapuntal writing techniques without damaging the poem's subtle musical qualities (Dyganova 2017).

This research work contributes to the musical literature in three ways. First, this study makes use of a multidimensional research model and contributes to the repertoire of educational and professional ensembles. Research reveals that Sofia Gubaidulina's music has not been sufficiently represented in concert programs (Dyganova 2017). For instance, the composition Hommage à Marina Tsvetaeva has not yet been sufficiently studied in the musicological literature. ${ }^{3}$ This is, in all likelihood, the first research work which explores this composition in the context of a cappella choral music.

Second, by examining such a capacious concept as counterpoint in Gubaidulina's choral music, this study provides a substantial contribution to the musicological literature on contemporary music (Dyganova 2017) and research which analyzes aspects of performing practice and issues of interpretation (Moskvina 2015 [1], and etc.). This work explores the genre archetypes in Hommage à Marina Tsvetaeva. Only a small number of research works has examined the various genre archetypes (Dyganova 2017), and their discoveries are not consistent (Lepri and Mcpherson 2019 [14]). For example, Lepri and Mcpherson discovered that the partially correct responses to the elements associated with the music's genre or instrumental usage were directly linked to the designer's background. This study analyzes the Hommage à Marina Tsvetaeva comprised of five movements and unearths three genre archetypes: namely, canon, psalmody, and motet. These discoveries continue along the line of Warwick's (2011 [20]) elaborations of the genre archetypes. These discoveries are consistent with Awang's (2016) semantic analysis of the influence of patriotic songs on people's hearts and minds. It also provides a response to Awang's (2016) call to examine utilized vocabulary (namely, selected words) in music and its effect on the listener's emotions. ${ }^{4}$

Finally, this study integrates practice and theory by proving the uniqueness of Sofia Gubaidulina's contrapuntal writing. However, with the presence of numerous genre archetypes, the multifaceted nature of the contrapuntal technique becomes all the more resourceful as an applied concept. In striving to uphold the organic trinity of the fundamental directions of musicology (history, theory and practice), this work explores the paradigm of choral music performance which reveals itself in Gubaidulina's music. For many decades composers have focused on writing music for grandiose choruses characterized by an intensification of chamber music-making, as manifested in instrumental, vocal and choral music (Kholopova 1973). In such performances every single performer essentially becomes a soloist. The increased interest of composers in chamber genres has led to the emergence of small choruses. For example, many arrangements for a cappella chorus have been made by many composers in the 20th century, such as Schnittke and Gubaidulina. ${ }^{5}$ However, these practices have not been researched. Therefore, this work brings all the practical aspects of music to the level of music theory. 


\section{Literature Review Polyphonic Music}

The earliest known polyphonic music dates back to the early 10th Century, which includes a setting of a short chant dedicated to St. Boniface, the patron saint of Germany (Plotnikova 2016 [2]; Helsen 2015 [12]). The term polyphony originates from Greek poluphōnia (from polu- "many" and phōnē "sound") and refers to a significant number of voices (Schneider and Zerfass 2019). Polyphony is associated with the independence of multiple voices or instruments (Schneider and Zerfass 2019 [18]). In polyphonic music, every participant is independent and part of a common polyphonic texture. ${ }^{6}$ However, the starting and ending point of any note or voice may overlap with the previous or the next note. Polyphonic music is always intentionally composed with a focus on independent melodic lines (Helsen 2015).

The earliest known polyphonic music comes from a collection known as The Winchester Troper (Bennett 2009 [6], and etc.). According to Bennett (2009), polyphonic music is mostly associated with Baroque and Renaissance music (Collins 2018 [8]), as well as composer Johann Sebastian Bach (Atwood 2019 [5]). Many different musical styles, such as canons, fugues, and Dixieland jazz, are considered to be polyphonic (Plotnikova 2016). According to Plotnikova (2016), in a canon a melody is played in canon the first time (the leading melody), and then after that a fixed set of times, the same melody is replayed (succeeding melody). The most popular canons are children's songs. ${ }^{7}$ A fugue introduces a melodic theme and imitates that theme throughout a piece (e.g., Baroque music Atwood 2019). A fugue differs from a canon in two ways. First, its melodic repetitions can make changes in the notes or rhythms (in leading and the subsequent melody). Second, a fugue contains different sections and lasts longer than a canon. Dixieland Jazz, also known as hot jazz or traditional jazz, emerged in the 1910s and 1920s in New Orleans (Leo 2020 [13]). A standard Dixieland jazz ensemble is comprised of a trumpet, clarinet and trombone as the main horn section, alongside a rhythmical instrumental section comprised of a double-bass, a piano, a guitar/ banjo, drums, and washboard (Leo 2020). In Dixieland Jazz, the trumpet, clarinet, and trombone play different, melodies, unrelated to each other throughout a song. The trumpet typically plays the leading melody, and the clarinet plays fast and intricate melodies, while the trombone plays a slower, more straightforward melody in the background (Leo 2020). There are usually two or more variations of a single melodic line played simultaneously. Two people sing the same melody, but one adds extra embellishing notes and variations, such as is usually done in Turkish, Arabic, Japanese, or Thai folk music.

Folk music constitutes a significant part of choral music. Contemporary choral music is characterized by innovative methods of sound production and a radical reassessment of its quality. It must be remembered, after all, that the present age is the time of the emergence of various new musical styles and techniques. These factors have transformed the vocal process of choral music (Phipps 2011 [17]; Dyganova 2017 [10]). The foundation of choral music aims at increasing the attention of composers and performers to the Gregorian chant and the traditions of Renaissance polyphony (Collins 2018 [8]), as well as to the Second Viennese School (Fanning and Assay 2019 
[11]; Artamonova 2019 [4]; Moskvina 2015 [1]). We can cite as an example, Luigi Dallapiccola's Dodecaphonic Bel Canto (Phipps 2011 [17]) comprised of a cycle of six pieces with written in the twelve-tone technique full chorus. Dallapiccola made full use of the dodecaphonic technique by organically merging it with intonations of various different ancient vocal music, such as the madrigal style, declamation, sensory perceptions of the words set to music, and characteristic intonations ${ }^{8}$ (Phipps 2011).

\section{Sofia Gubaidulina}

Sofia Gubaidulina is a contemporary composer whose music is characterized by philosophical depth, high spirituality, and vivid emotionality (Dyganova 2017). Her artistic heritage includes various musical genres and compositions that are complex and diverse, including music for a capella chorus, ${ }^{9}$ the choral suite Hommage à Marina Tsvetaeva and arrangements of folk songs. Although Gubaidulina's choral works are few in number, they have formed a critical foundation, which characterizes the features of many composers' styles. Unfortunately, Gubaidulina has not been composing in choral genres in recent years; she explained that her compositions are not in demand.

The suite Hommage à Marina Tsvetaeva is composed of five pieces for full chorus a cappella, the titles of which are: Fallen Deeper than the Waves, The Horse, Splendour of the Pipes Interlude, and The Garden. Gubaidulina used four poems by Marina Tsvetaeva in her suite and combined two separate lines from previous movements of the cycle to create The Interlude (Lukomsky 1999 [16]). In Hommage à Marina Tsvetaeva the poetic text presents a multi-layered structure. Emotionally, the suite demonstrates a combination of external and internal conflict; dramatically, it is a composition consisting of five examples of Fabula and narration..$^{10}$ Hommage à Marina Tsvetaeva was composed when Tsvetaeva returned to her homeland and was engulfed by the whirlwind of the Soviet reality. She felt like a stranger because everyone around her proved to be a liar and hypocrite and glorified pagan idols (e.g., the leader, themselves, or Satan). It is typical to include Gubaidulina in the Big Troika of the late-Soviet avant-garde musical movement (Chambers and Krivosheyev 2016 [7]). As emphasized by the leading figures of contemporary choral performing arts, the choral heritage of modern composers (Chambers and Krivosheyev 2016; Dyganova 2017) presents the most exciting material for choral singers. Choral avant-garde music is characterized by a new perception of sound, dissonant chords, free chromaticism, an uneven pulse, an innovative musical language, and a combination of sharply contrasting singing techniques (Fanning and Assay 2019; Artamonova 2019; Moskvina 2015; Phipps 2011).

In Gubaidulina's choral output the vocal techniques are complex and difficult to perform (Lukomsky 1999). They are similar to dramatic actors' speech, where great importance is attached to the intonation. The composer considers choral voices as multifaceted and capable of producing various vocal and speech techniques. For instance, unlike many other contemporary techniques of writing for the chorus, breath-like singing is easy to perform. Gubaidulina made a considerable amount of use of different modern performing techniques, such as bringing in numerous divisi that turn chorus singers into soloists. Moreover, 
the use of non-fixed pitches of sounds and non-traditional methods of articulation are also widespread techniques of choral sonorics (Dyganova 2017). The suite's choral texture is comprised of sound complexes (sonors), in which not only individual intervals, but also regular sounds are indistinguishable. The use of frequent glissandi in various forms leads to the formation of microtonality, as well as a random combination of sounds due to the alternate introduction of choral parts simultaneously performing different vocal and speech-like techniques (including aleatory relationships of sounds), ${ }^{11}$ and etc.

A striking example of sonorism, which is partly similar to the methods of Gubaidulina, is the third movement of Ligeti's Requiem (Levy 2013 [15]). The words, being whispered, are divided into syllables of relatively short durations (eighths and triplet eighths). Since these syllables are rhythmically stressed, the exact pitch and structure of the chords may not be audible. As Ligeti (Levy 2013, mm. 35-46) observed, the intonation is outlined only in general terms. Gubaidulina made use of choral sonorism, where a consonance is whispered, while another one replaces the leading consonance. It is difficult to differentiate these two consonances.

\section{Research Questions}

In order to fulfill our research objectives, the following research questions have been developed:

RQ1: Can Gubaidulina's polyphonic technique and genre archetypes be revealed through semantic analysis?

RQ2: Can Gubaidulina's vocal techniques and sounds be distinguished in the composition?

\section{Methodology and Procedure}

This study analyzes the five movements of Sofia Gubaidulina's choral suite Hommage à Marina Tsvetaeva. The five movements (Table 1, column 2) are then analyzed using a multi-modal research design. Moreover, it uses semantic analysis to examine the stylistic features of the contrapuntal writing of Sofia Gubaidulina's music. This study extracts data for the analysis from each movement. The simultaneously selected movements were taken by means of extraction of key words. Moreover, Valentina Kholopova's expression parameter was used to analyze each movement's emotional parameters. According to Kholopova, Gubaidulina's compositions are usually grouped into five expression parameters (EP), which are articulation and sound production, melody, rhythm, texture, and compositional writing. These parameters are typically used as either consonant or dissonant EPs.

\section{Data Analysis}

The objective of the data analysis is to determine the lyrics and text used in the five movements, using semantic analysis. The keyword extraction was performed to identify words in lyrics and semantic contexts or the characteristics of the choice of words in the lyrics. The keywords (synonyms and antonyms) were double-checked by Russian linguists from a large university in Russia. The data analysis process went through two steps: (1) synonyms and antonyms were developed for each movement through word clustering, and (2) the movements were then assigned several clusters to identify the genre archetype, polyphonic techniques, and compositional techniques. The five movements were grouped into five consonant and five dissonant EPs. 
These EPs were generated by analyzing the keywords and linking them to their respective themes.

\section{Results}

RQ1: Can Gubaidulina's polyphonic technique and genre archetypes be revealed through semantic analysis?

Gubaidulina's polyphonic technique in a cappella choral music is revealed in synthesizing the poetic and musical text. Table 1 shows that all five movements can be categorized according to the genre archetype, polyphonic technique, and sonoric technique. The results of the word and lyric extraction reveal that each movement has a renewed musical language, sometimes achieved by a combination of sharply contrasting, literary and folk, singing techniques. These words and lyrics are characterized by philosophical depth, high spirituality, and vivid emotionality. These characteristic features are revealed in the third and fifth movements, which incorporate psalmody. In these movements the composer makes use of a different type of psalmody. In the third movement an antiphonal chant is used, which produces allusions to the Gregorian chant. In the fifth movement a responsorial psalmody is complemented by polyphonic cluster chords in the background (in the bass). The fourth movement combines a continuous imitation technique supplemented by sonoristicaleatoric compositional techniques with the archetype of a motet. The arrangement was inspired by early music genres and modern composition techniques. These discoveries answer our first research question.

The analysis of Gubaidulina's Hommage à Marina Tsvetaeva reveals the theme in its primary form (Example 1) and a reversed theme in the ultra-contrapuntal choral parts (Example 2). In the fifth movement
(The Garden), the soloist synthesizes allusions to the lyric sixth, which correlates the motives with the previous movements' themes. In the choral part clusters diverge in different directions in the volume of a diminished fourth, which appears in response to the soloist's calls. This technique indirectly refers to the intervallic structure of the first movement of the cycle. In sum, the development of the musical themes in the composition is replaced by the development of the overall poetic idea.

Example 1 The beginning of Sofia Gubaidulina's Fallen Deeper than the Waves (Movement 1)

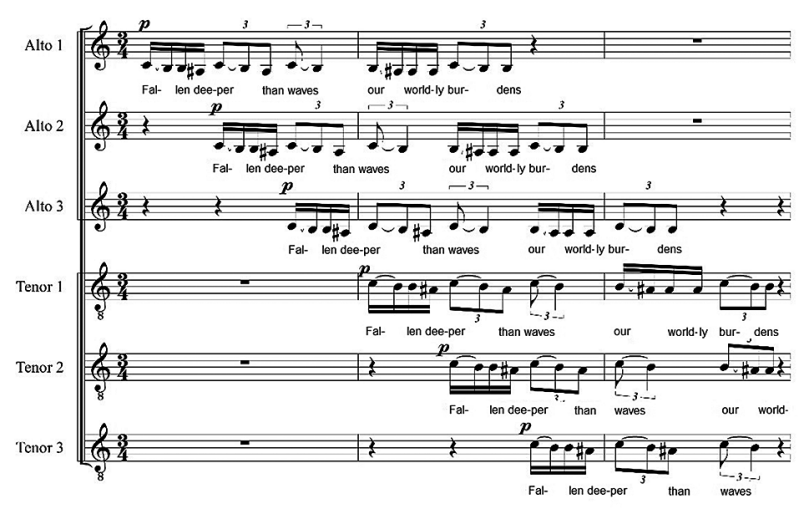

Example 2 Measures 5-9 of Sofia Gubaidulina's Fallen Deeper than Waves (Movement 1)

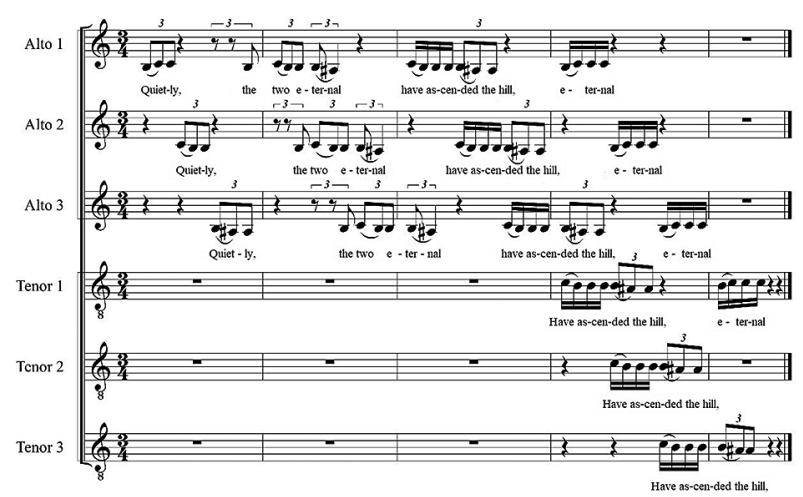

As shown in Example 3, Gubaidulina followed the pointillist technique (Phipps 2011) by placing sound points in different registers and separating them with prolonged pauses. Example 4 shows the 
use of antiphonal psalmody in the third movement. The musical and textual material appears three times between different groups of the chorus. Continuous imitation is the technique that culminates the fourth movement (Interlude). As shown in Example 5, the text's emotional coloring develops from imitations through the double canon to the chant, made use of chords that complete this movement in the fifth movement. These discoveries answer our second research question.

Example 3 The beginning of Sofia Gubaidulina's Horse (Movement 2)

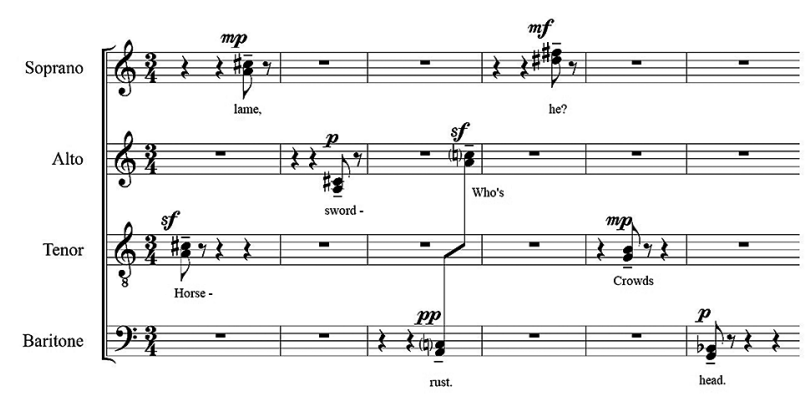

Example 4

Sofia Gubaidulina's Splendor of the Pipes (Movement 3)

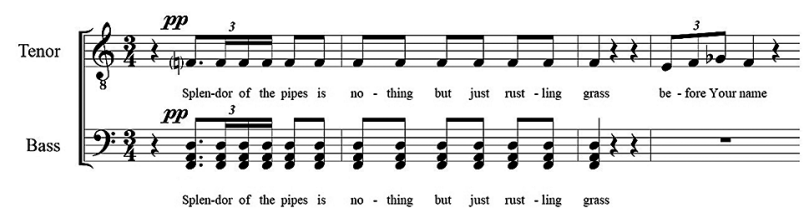

RQ2: Can Gubaidulina's vocal techniques and sounds be distinguished in the composition?

Gubaidulina used fourteen different vocal techniques in her composition. The vocal techniques include singing, breathy singing, intoned speech, intoned breathy speech, direct speech, breathy speech, whisper, breath sound-in, and breath soundout. The sounds are notated as soorities with approximate pitches, indeterminate pitches, glissading speech, non-rhythmical glissading speech, and sequential increasing in pitch with an undefined non-fixed pitch. The vocalist used the lower part of the vocal range, which causes intonation inaccuracies in the composition.

These discoveries reveal that the composer used varied vocal techniques and sounds in her composition. In the fourth movement (the Iinterlude), the composer incorporated intoned speech (commonly known as “sprechgesang," Covach 2018 [9]), intoned breathy sound, and plain-breathy speech. Intoned speech (sprechgesang) is demonstrated by the composer's use of adjectives such as delightedly, joyfully, enthusiastically, festively, frivolously, thoughtfully, with great dignity (with welltrained voice), affirmatively (with crying out), and terrifyingly affirmative. These adjectives change the vibrant color of the fourth movement. Intoned breathy sounds are dynamically low but have a greater expressive variety. Plain and breathy speech is a technique that makes speech slurred and causes dynamic decay. Breathing sounds-in and -out were used in the fifth movement (The Garden). To produce these sounds effectively, the performers have to perform in halls with extraordinary acoustic capabilities. The listener may interpret these sounds as simple moaning. The glissading speech was used in the texts of the third (Splendor of the Pipes) and fourth movements (Interlude). In these movements the composer dramatically used the words and by passing them through a series of rhythmic, intonational, and dynamic transformations. These discoveries answer our third research question.

\section{Discussions}

The five movements of this cycle are influenced by early music genres and contemporary composition techniques. 
Marina Tsvetaeva's poems have unified all the five movements. Sofia Gubaidulina's composition conveys the poetical text in a multi-layered structure. Therefore, this study fulfills its objective of examining Hommage à Marina Tsvetaeva's composition by Sofia Gubaidulina in the following way.

First, this work employed a multidimensional research design to extrapolate the genre archetypes, polyphonic techniques, and modern composition techniques of the five movements of the cycle. The discoveries presented in Table 1 present us with grounds to assert that Gubaidulina's interpretation of Hommage à Marina Tsvetaeva can be subdivided into three genre archetypes (canon, motet, and psalmody), four polyphonic techniques (canonical imitation, hoquet, antiphon, and continuous imitation), and four compositional techniques (sonorism, pointillism, allusions, and sonoricaleatory technique). The analysis of the fourth movement also reveals the use of semantics to evoke the listeners' emotions and enhance their understanding of the composition.

Second, the study introduces a capacious concept of genre archetypes in Gubaidulina's music and Hommage à Marina Tsvetaeva. This research identifies three genre archetypes (canon, psalmody, and motet) in the five movements. These archetypes reflect a renewed choral texture. For instance, the genre prototype of the first movement is canon, which elicited symbols of spirituality and infinity of categories. The second movement's genre prototype is the early historical genre of hoquet, which has been neglected by composers for a lengthy period of time, but was revived in the pointillism prominent among the works by the composers of the Second Viennese School. Gubaidulina followed
Anton Webern's pointillist aesthetic canons (Sternberg, Kaufman, and Pretz 2001 [19]) by placing sound points in different registers and separating them with prolonged pauses. (Example 3). As shown in Example 4, the third movement is an antiphonal psalmody. Here, musical and textual material appears three times between the different choral groups. Stylistically, the music alludes to the Early Middle Ages and the rigid rhythmic compositions exemplified by that era.

Finally, this study unveils that the polyphonic technique's multifaceted nature is resourceful as an applied concept. Continuous imitation is the technique of the culminating movement titled Interlude. A short motive with the words that Splendour of the Pipes goes through various emotional and psychological states, from soft intonation to affirmative fervor. It is also noteworthy that, following the song text's vibrant coloring, the polyphonic technique develops from imitations through the double canon to the chant using chords that complete this movement of the suite (Example 5). The final piece, entitled The Garden, is based on the genre archetype of psalmody.

Example 5 The begging of Sofia Gubaidulina's Interlude (Movement 4)

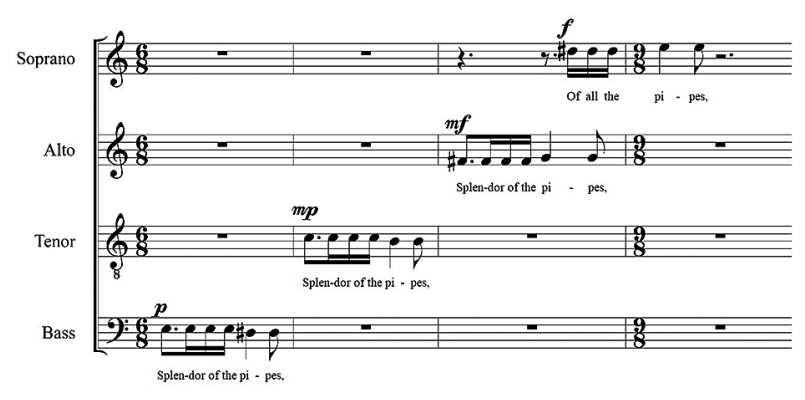

In contrast to the previous movement, in this movement this study discovers a responsive type of psalmody, with calls and responses between the soloist and 
the chorus. The soloist's part synthesizes allusions to the lyrical sixth movement, which is typical of the works by 19th century Romantic composers (Dyganova 2017). This lyrical movement is complemented by the correlation of motives with the themes of the previous movements. In the choral part clusters diverge in different directions in the range of a diminished fourth, which appears in response to the soloist's calls. This technique produces an indirect reference to the intervallic structure of the first movement of the cycle.

\section{Conclusions}

The musical art of the late 20th and early 21 st Centuries is replete with innovative ideas and techniques. In particular, choral polyphony emphasizes the role of symbolism and irrationality. Hommage à Marina Tsvetaeva by Sofia Gubaidulina is one of the most impressive examples of contemporary choral music. This composition for a cappella chorus makes use of new techniques. Moreover, the composer conveys the poetics of Tsvetaeva's text in a nuanced way. In Sofia Gubaidulina's choral work the artistic text is presented as a multi-layered structure. Emotionally, the suite shows a combination of external and internal conflict, while dramatically, it demonstrates a combination of narrative and narration. The narrative of the fivemovement composition is presented by four poetic texts written at different times. These texts were selected because of the most potent manifestation of central ideas in the works of Tsvetaeva.

\section{Oro APPENDIX oro}

Table 1: Movements in Hommage à Marina Tsvetaeva by Sofia Gubaidulina

\begin{tabular}{|c|l|l|l|l|}
\hline No. & Title & Genre Archetype & Polyphonic Technique & The compositional Technique \\
\hline 1 & Fallen Deeper than Waves & Canon & Canonical imitation & Sonoric \\
\hline 2 & The Horse & Motet & Hoquet & Pointillism \\
\hline 3 & Splendor of the Pipes & Psalmody & Antiphon & Allusions \\
\hline 4 & Interlude & Motet & Continuity imitation & Sonoric-aleatoric \\
\hline 5 & The Garden & Psalmody & Responsory & Sonoric \\
\hline
\end{tabular}

\section{Oro NOTES Oro}

1 Bohlman P. V., Celestini F. Editorial: Reckoning with Musicology's Past and Present. Acta Musicologica: International Musicological Society. 2020. Vol. 92, No. 2, pp. 117-119.

2 Awang A. A., Lokman A. M., Fathir M. F. M., Salleh S. M. A Semantic Analysis of Malaysia's Patriotic Songs. Advanced Science Letters. 2016. Vol. 22, No. 5, pp. 1373-1379.

DOI: 10.1166/asl.2016.6616.

3 Bohlman P. V., Celestini F. Editorial: Reckoning with Musicology’s Past and Present. Acta Musicologica: International Musicological Society. 2020. Vol. 92, No. 2, pp. 117-119 .

4 Awang A. A., Lokman A. M., Fathir M. F. M., Salleh S. M. Op. cit. 
5 Daunoravičienė G. Classes and Schools of Lithuanian Composers: A Genealogical Discourse. Lituanistika. 2018. Vol. 19, pp. 121-160.

6 Szamosi G. Polyphonic Music and Classical Physics: The Origin of Newtonian Time. History of Science. 1990. Vol. 28, No. 2, pp. 175-91. DOI: 10.1177/007327539002800203.

7 Raju M., Välja L., Ross J. Estonian Children's Improvisational Songs, the Nature of Performance and Songs' Coherence with the Western Tonal Musical Canon. Musicae Scientiae. 2015. Vol. 19, No. 3, pp. 282-300. DOI: 10.1177/1029864915598663.

8 Mangani M., and Sabaino D. Tonal Types and Modal Attributions in Late Renaissance Polyphony: New Observations. Acta Musicologica. 2008. Vol. 80, No. 2, pp. 231-250.

9 Lupishko M. On the 'Melodic Quality' of Tsvetaeva's Lyric Verse: Hommage à Marina Tsvetayeva by Sofia Gubaidulina (1984). Russian Émigré Culture: Transcending the Borders of Countries, Languages, and Disciplines.2018. URL:

https://www.academia.edu/38242825/On_the_Melodic_Quality_of_Tsvetaeva_s_Lyric_Verse_Hommage_à_Marina_Tsvetayeva_by_Sofia_Gubaidulina_1984_ (25.07.2021).

${ }^{10}$ Lupishko M. On the 'Melodic Quality' of Tsvetaeva's Lyric Verse: Hommage à Marina Tsvetayeva by Sofia Gubaidulina (1984). Russian Émigré Culture: Transcending the Borders of Countries, Languages, and Disciplines.2018. URL:

https://www.academia.edu/38242825/On_the_Melodic_Quality_of_Tsvetaeva_s_Lyric_Verse_Hommage_à_Marina_Tsvetayeva_by_Sofia_Gubaidulina_1984_ (25.07.2021).

${ }^{11}$ Bernard J. W. Voice Leading as a Spatial Function in the Music of Ligeti. Music Analysis. 1994. Vol. 13, No. 2/3, p. 227. DOI: $10.2307 / 854260$.

\section{Or REFERENCES}

1. Moskvina O. A. "Dve tropy" S. Gubaydulinoy: lyubov' zemnaya i lyubov' nebesnaya (prochtenie "syuzheta" o Marii i Marfe v kontserte dlya dvukh solistov i orkestra) [The "Two Paths" of Sofia Gubaidulina: Earthly Love and Heavenly Love (Reading The 'Plot' About Maria and Marpha In The Concerto For Two Soloists and Orchestra)]. Istoricheskie, filosofskie, politicheskie $i$ yuridicheskie nauki, kul'turologiya $i$ iskusstvovedenie. Voprosy teorii i praktiki [Historical, Philosophical, Political and Legal Sciences, Cultural Studies and Art History. Questions of Theory and Practice]. 2015. Vol. 9, No. 59, pp. 118-124.

2. Plotnikova N. Yu. Otekhnike kanona v muzyke russkogo barokko: Na primere polikhoral'nykh proizvedeniy Vasiliya Titova [On the Technique of the Canon in the Music of the Russian Baroque: On the Example of the Polychoral Works of Vasily Titov]. Moscow: Nauka, 2016. 347 p.

3. Kholopova V. N. Ob odnom printsipe khromatiki v muzyke XX veka [On one Principle of Chromaticism in the Music of the 20th Century]. Problemy muzykal'noy nauki [Issues of Musical Scholarship]. Vol. 2. Moscow, 1973. 331 p.

4. Artamonova E. Multifaceted Creativity: Legacy of Alexander Ivashkin Based on Archival Materials and Publications. Proceedings of the 3rd International Conference on Art Studies: Science, Experience, Education. Ed. E. Artamonova. Paris: Atlantis Press, 2019, p. 162.

DOI: 10.2991/icassee-19.2019.165.

5. Atwood G. E. Time, Death, Eternity: Imagining the Soul of Johann Sebastian Bach. New Trends in Psychobiography. Eds. C. H. Mayer, Z. Kovary. Cham: Springer International Publishing, 2019, pp. 299-323. DOI: 10.1007/978-3-030-16953-4_17. 
6. Bennett D. D. The Winchester Troper. Speculum. 2009. Vol. 84, No. 2, pp. 487-488. DOI: $10.1017 / \mathrm{S} 0038713400018662$.

7. Chambers D., Krivosheyev M. Mikhail Butkevich: The Bridge to the Contemporary Russian Avant-Garde. Stanislavski Studies. 2016. Vol. 4, No. 2, pp. 125-135.

DOI: 10.1080/20567790.2016.1234017.

8. Collins D. Approaching Renaissance Music Using Taneyev's Theories of Movable Counterpoint. Acta Musicologica. 2018. Vol. 90, No. 2, pp. 178-201.

9. Covach J. The Americanization of Arnold Schoenberg? Theory, Analysis, and Reception. Journal of the German-Speaking Society of Music Theory. 2018. Vol. 15, No. 2, pp. 155-175. DOI: $10.31751 / 991$.

10. Dyganova E. Sofia Gubaidulina's "Dedication to Marina Tsvetaeva" as the Example of Staginess in Choral Performance. 4th International Multidisciplinary Scientific Conferences on Social Sciences and Arts SGEM 2017: Conference Proceedings. Book 6. Science and Arts. Volume II, pp. 207-214.

11. Fanning D., Assay M. Shostakovich's 'Leningrad' Symphony. The Routledge Handbook to Music under German Occupation, 1938-1945. Eds. D. Fanning, M. Assay. Routledge: Arts, 2019, pp. 418-447. DOI: 10.4324/9781315230610-22.

12. Helsen K. Neumes for Novices. Early Music. 2015. Vol. 43, No. 2, pp. 319-320.

DOI: $10.1093 / \mathrm{em} / \mathrm{cav} 028$.

13. Leo K. M. Early Blues and Jazz Authorship in the Case of the 'Livery Stable Blues. Jazz Perspectives. 2020. Vol. 12, No. 3, pp. 311-338. DOI: 10.1080/17494060.2020.1833071.

14. Lepri G., McPherson A. Fictional Instruments, Real Values: Discovering Musical Backgrounds with Non-Functional Prototypes. Proceedings of the 2019 Conference on New Interfaces for Musical Expression. 2019, pp. 122-127.

URL: https://zenodo.org/record/3672890\#.YS9mZ7AzbIU (25.07.2021).

15. Levy B. R. Rules as Strict as Palestrina's': The Regulation of Pitch and Rhythm in Ligeti's Requiem and Lux Aeterna. Twentieth-Century Music. 2013. Vol. 10, No. 2, pp. 203-230.

DOI: $10.1017 / \mathrm{S} 1478572213000029$.

16. Lukomsky V. 'Hearing the Subconscious': Interview with Sofia Gubaidulina. Cambridge: Cambridge University Press, 1999. 31 p. URL: https://www.jstor.org/stable/946672?seq=1.

17. Phipps G. H. The Twelve-Tone Music of Luigi Dallapiccola. Notes. 2011. Vol. 68, No. 1, pp. 102-105. DOI: 10.1353/not.2011.0104.

18. Schneider L., Ansgar Z. Polyphony in Corporate and Organizational Communications: Exploring the Roots and Characteristics of a New Paradigm. Communication Management Review. 2019. Vol. 3, No. 2, pp. 6-29. DOI: 10.22522/cmr20180232.

19. Sternberg R. J., Kaufman J. C., Pretz J. E. The Propulsion Model of Creative Contributions Applied to the Arts and Letters. The Journal of Creative Behavior. 2001. Vol. 35, No. 2, pp. 75-101. DOI: 10.1002/j.2162-6057.2001.tb01223.x.

20. Warwick E. Word Setting in a Perfect Musical World: The Case of Obrecht's Motets. Journal of the Alamire Foundation. 2017. Vol. 3, No. 1, pp. 52-75. DOI: 10.1484/J.JAF.1.102193.

About the author:

Natalya V. Koshkareva, Ph.D. (Arts), Professor, Head of the Academic Choral Conducting Department, State Musical Pedagogical Institute named after M. M. Ippolitov-Ivanov (109147, Moscow, Russia), ORCID: 0000-0003-3831-3419, nkoshkarevav@gmail.com 


\section{Or МИТЕРАТУРА $\sqrt{ }$}

1. Москвина О. А. «Две тропы» С. Губайдулиной: любовь земная и любовь небесная (прочтение «сюжета» о Марии и Марфе в концерте для двух солистов и оркестра) // Исторические, философские, политические и юридические науки, культурология и искусствоведение. Вопросы теории и практики. 2015. Т. 9, № 59. С. 118-124.

2. Плотникова Н. Ю. О технике канона в музыке русского барокко. На примере полихоральных произведений Василия Титова. М.: Наука, 2016. 347 с.

3. Холопова В. Н. Об одном принципе хроматики в музыке ХХ века // Проблемы музыкальной науки / сост. В. Н. Холопова. М., 1973. 331 с.

4. Artamonova E. Multifaceted Creativity: Legacy of Alexander Ivashkin Based on Archival Materials and Publications // Proceedings of the 3rd International Conference on Art Studies: Science, Experience, Education / Ed. E. Artamonova. Paris: Atlantis Press, 2019, p. 162.

DOI: 10.2991/icassee-19.2019.165.

5. Atwood G. E. Time, Death, Eternity: Imagining the Soul of Johann Sebastian Bach // New Trends in Psychobiography / Eds. C. H. Mayer, Z. Kovary. Cham: Springer International Publishing, 2019, pp. 299-323. DOI: 10.1007/978-3-030-16953-4_17.

6. Bennett D. D. The Winchester Troper// Speculum. 2009. Vol. 84, No. 2, pp. 487-488.

DOI: $10.1017 / \mathrm{S} 0038713400018662$.

7. Chambers D., Krivosheyev M. Mikhail Butkevich: The Bridge to the Contemporary Russian Avant-Garde // Stanislavski Studies. 2016. Vol. 4, No. 2, pp. 125-135.

DOI: $10.1080 / 20567790.2016 .1234017$.

8. Collins D. Approaching Renaissance Music Using Taneyev's Theories of Movable Counterpoint // Acta Musicologica. 2018. Vol. 90, No. 2, pp. 178-201.

9. Covach J. The Americanization of Arnold Schoenberg? Theory, Analysis, and Reception // Journal of the German-Speaking Society of Music Theory. 2018. Vol. 15, No. 2, pp. 155-175. DOI: $10.31751 / 991$.

10. Dyganova E. Sofia Gubaidulina's "Dedication to Marina Tsvetaeva" as the Example of Staginess in Choral Performance // 4th International Multidisciplinary Scientific Conferences on Social Sciences and Arts SGEM 2017: Conference Proceedings. Book 6. Science and Arts. Volume II, pp. 207-214.

11. Fanning D., Assay M. Shostakovich's 'Leningrad' Symphony // The Routledge Handbook to Music under German Occupation, 1938-1945 / Eds. D. Fanning, M. Assay. Routledge: Arts, 2019, pp. 418-447. DOI: 10.4324/9781315230610-22.

12. Helsen K. Neumes for Novices // Early Music. 2015. Vol. 43, No. 2, pp. 319-320.

DOI: $10.1093 / \mathrm{em} / \mathrm{cav028}$.

13. Leo K. M. Early Blues and Jazz Authorship in the Case of the 'Livery Stable Blues // Jazz Perspectives. 2020. Vol. 12, No. 3, pp. 311-338. DOI: 10.1080/17494060.2020.1833071.

14. Lepri G., McPherson A. Fictional Instruments, Real Values: Discovering Musical Backgrounds with Non-Functional Prototypes // Proceedings of the 2019 Conference on New Interfaces for Musical Expression. 2019, pp. 122-127.

URL: https://zenodo.org/record/3672890\#.YS9mZ7AzbIU (25.07.2021).

15. Levy B. R. Rules as Strict as Palestrina's': The Regulation of Pitch and Rhythm in Ligeti's Requiem and Lux Aeterna // Twentieth-Century Music. 2013. Vol. 10, No. 2, pp. 203-230. DOI: $10.1017 / \mathrm{S} 1478572213000029$. 
16. Lukomsky V. 'Hearing the Subconscious': Interview with Sofia Gubaidulina. Cambridge: Cambridge University Press, 1999. 31 p. URL: https://www.jstor.org/stable/946672?seq=1.

17. Phipps G. H. The Twelve-Tone Music of Luigi Dallapiccola// Notes. 2011. Vol. 68, No. 1, pp. 102-105. DOI: 10.1353/not.2011.0104.

18. Schneider L., Ansgar Z. Polyphony in Corporate and Organizational Communications: Exploring the Roots and Characteristics of a New Paradigm // Communication Management Review. 2019. Vol. 3, No. 2, pp. 6-29. DOI: 10.22522/cmr20180232.

19. Sternberg R. J., Kaufman J. C., Pretz J. E. The Propulsion Model of Creative Contributions Applied to the Arts and Letters // The Journal of Creative Behavior. 2001. Vol. 35, No. 2, pp. 75-101. DOI: 10.1002/j.2162-6057.2001.tb01223.x.

20. Warwick E. Word Setting in a Perfect Musical World: The Case of Obrecht's Motets // Journal of the Alamire Foundation. 2017. Vol. 3, No. 1, pp. 52-75. DOI: 10.1484/J.JAF.1.102193.

\section{Об авторе:}

Кошкарева Наталья Владимировна, кандидат искусствоведения, профессор, заведующая кафедрой дирижирования академическим хором, Государственный музыкально-педагогический институт имени М. М. Ипполитова-Иванова (109147, г. Москва, Россия), ORCID: 0000-0003-3831-3419, nkoshkarevav@gmail.com 